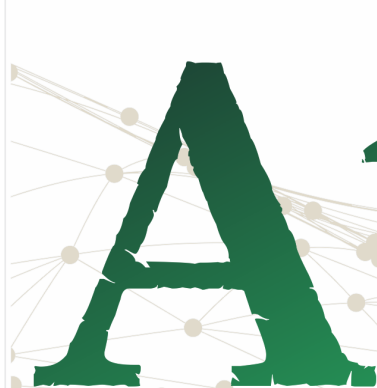

ISSN n² 2526-8031

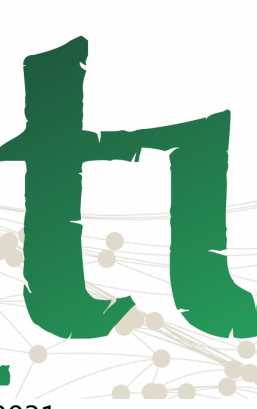

tur

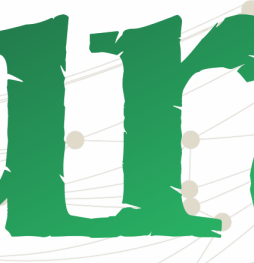

.

.

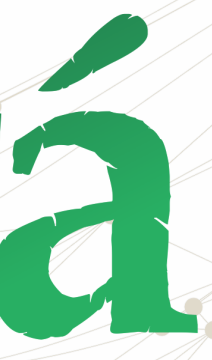

Pan-Amazônica

de Comunicação

\title{
CONTRIBUICÕES TEÓRICAS SOBRE A JUSTIÇA NAS PERSPECTIVAS ANALÍTICAS DE AXEL HONNET E NANCY FRASER
}

Theoretical contributions of justice from the analytical perspectives of Axel Honnet and Nancy Fraser

Aportes teóricos sobre la justicia desde las perspectivas analíticas de Axel Honnet y Nancy Fraser

\section{Maria Cotinha Bezerra Pereira ${ }^{1}$}

\section{RESUMO}

O presente texto traz a percepção da manifestação das pessoas com respeito ao sentimento de descrença para com as instituições e agentes públicos, a perda de autoestima, a deterioração das relações interpessoais e dos vínculos indivíduo-indivíduo e indivíduo-sociedade, uma estranha naturalização e banalização da violência. Esse conjunto de situações tornou-se mais discursivo e verbalizado por meio de redes sociais digitais de comunicação, nas quais as pessoas, das mais diversidades matizes socioculturais expressam opiniões, compartilham informações verdadeiras ou não e, por fim, estabelecem tribunais virtuais com presunção de culpa dos sujeitos sobre situações e fatos ocorridos. Objetiva-se com a presente reflexão abordar os conceitos de civilização, barbárie e justiça, em seus prismas filosófico e sociológico. Frente a essa realidade. Realizou-se mapeamento das produções acadêmicas, selecionou-se as contribuições de Axel Honneth, e Nancy Fraser, além da interlocução com estudiosos de distintas áreas. A reflexão conduziu a proposta de aliar parte das contribuições de Axel Honneth e Nancy Fraser sobre a importância da redistribuição, do reconhecimento e da participação na prática da justiça pelos cidadãos no contexto regional tocantinense e pan-amazônico.

PALAVRA-CHAVE: Justiça. Teoria. Reconhecimento. Igualdade. Democracia.

1 Graduada em Direito pela Pontifícia Universidade Católica de Goiás (1988), Especialista em Direito Penal e Processual Penal (1997), Especialista em Estado de Direito e Combate à Corrupção (2017). Mestranda em Prestação Jurisdicional e Direitos Humanos. Procuradora-Geral e $4^{\text {a }}$ Procuradora de Justiça do Ministério Público do Estado do Tocantins. E-mail: mariacbp100@gmail.com. C.Lattes: http://lattes.cnpq.br/ 5023136633990800. Orcid n. ${ }^{\circ}$ 0000-0001-7318-5649 


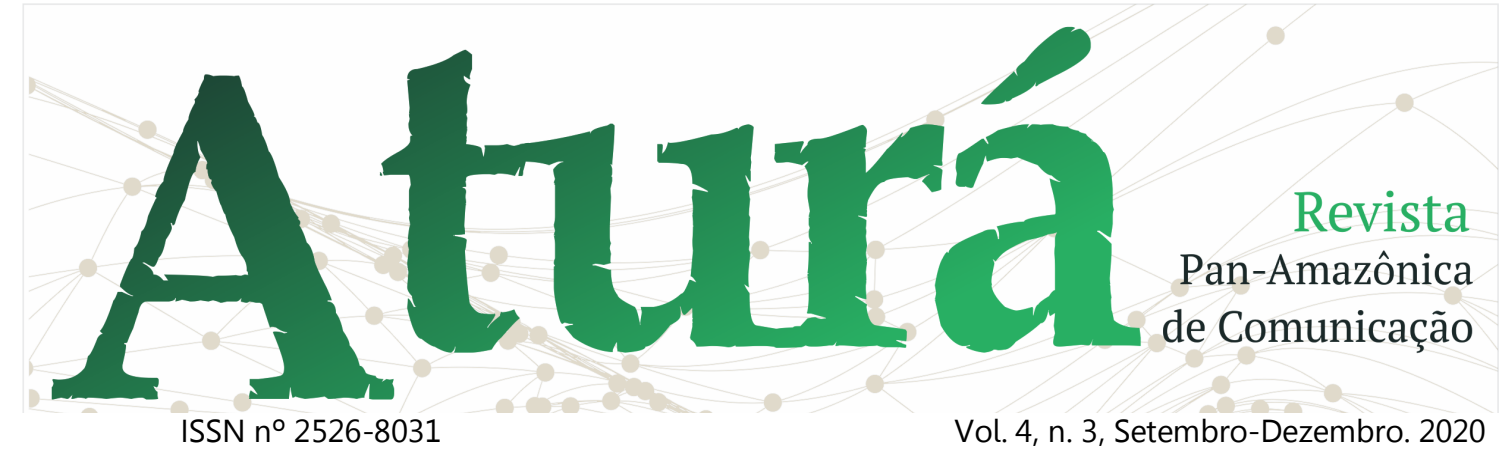

\begin{abstract}
This text considers people's perception of the reproach feeling towards institutions and public agents, the deterioration of interpersonal relationships and the individual-individual and individual-society bonds, a strange naturalization and trivialization of violence. This set of situations has become more discursive and verbalized through digital social communication networks, in which people, from the most diverse socio-cultural hues express opinions, share true or untrue information and, finally, establish virtual courts with presumption of guilt. of subjects about situations and facts that occurred. The aim of this reflection is to address the concepts of civilization, barbarism and justice, in their philosophical and sociological prisms. Faced with this reality, mapping of academic productions was carried out, the contributions of Axel Honneth, and Nancy Fraser were selected, in addition to interlocution with scholars from different areas. The reflection led to the proposal to combine part of the contributions of Axel Honneth and Nancy Fraser on the importance of redistribution, recognition and participation in the practice of justice by citizens in the regional context of Tocantins and Pan-Amazon.
\end{abstract}

KEYWORD: Justice. Theory. Recognition. Equality. Democracy

\title{
RESUMEN
}

Este texto considera la percepción de las personas sobre el sentimiento de reproche hacia las instituciones y los agentes públicos, el deterioro de las relaciones interpersonales y los lazos individuales-individuales y entre la sociedad, una extraña naturalización y trivialización de la violencia. Este conjunto de situaciones se ha vuelto más discursivo y verbalizado a través de redes digitales de comunicación social, en las cuales las personas, desde los más diversos tonos socioculturales expresan opiniones, comparten información verdadera o falsa y, finalmente, establecen tribunales virtuales con presunción de culpa de Is sujetos sobre situaciones y hechos que ocurrieron. El objetivo de esta reflexión es abordar los conceptos de civilización, barbarie y justicia, en sus prismas filosóficos y sociológicos. Ante esta realidad, se realizó un mapeo de producciones académicas, se seleccionaron las contribuciones de Axel Honneth y Nancy Fraser, además de la interlocución con académicos de diferentes áreas. La reflexión llevó a la propuesta de combinar parte de las contribuciones de Axel Honneth y Nancy Fraser sobre la importancia de la redistribución, el reconocimiento y la participación en la práctica de la justicia por parte de los ciudadanos en el contexto regional del Tocantins (Brasil) y la Panamazonía.

PALABRAS CLAVE: Justicia. Teoría. Reconocimiento. Igualdad. Democracía. 


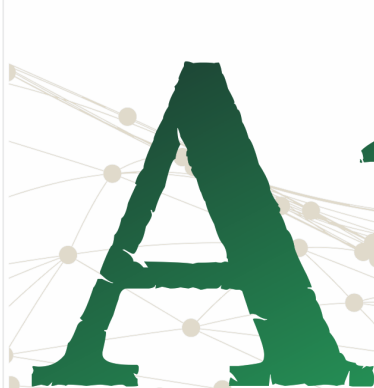

ISSN n०2526-8031
Revista

Pan-Amazônica

de Comunicação

Vol. 4, n. 3, Setembro-Dezembro. 2020

\section{Introdução}

O presente texto tem como ponto de partida a percepção da manifestação das pessoas com respeito ao sentimento de insegurança vivida e sentida para com as instituições e agentes públicos, à sensação manifesta de perda de autoestima, a deterioração das relações interpessoais e dos vínculos indivíduoindivíduo e indivíduo-sociedade, uma estranha naturalização e banalização da violência. Esse conjunto de situações tornou-se mais discursivo e verbalizado por meio de redes sociais digitais de comunicação, nas quais as pessoas, das mais diversidades matizes socioculturais expressam opiniões, compartilham informações verdadeiras ou não e, por fim, estabelecem tribunais virtuais com presunção de culpa dos sujeitos sobre situações e fatos ocorridos.

Existe um pressuposto, de forma tácita, por parte das pessoas usuárias das redes sociais - seja pelos aplicativos de comunicação imediata, seja pela internet -, dos meios de comunicação convencionais como a televisão, jornais e as emissoras de rádio, de que se pode estar vivendo numa sociedade com ausência parcial ou total da justiça. Havendo com isso também, a revitalização de um desejo que motiva a desejar que a justiça seja algo praticado imediato e instantaneamente.

Além disso, as pessoas usuárias dessas mídias digitalizadas deram passos largos, subsidiadas por grupos ideológicos distintos, para irem além da difusão de conteúdos de tal natureza, agora elas também são desenvolvedoras ou coprodutoras. Opiniões sobre fatos e acontecimentos são extrapoladas, ganhando notoriedade e plausibilidade pelos grupos de usuários com normatividade doutrinária.

Para além da análise dos produtos e dispositivos midiáticos e sua relação com o comportamento dos cidadãos usuários, a partir do lugar de atuação profissional e sensível ao que se vem observando nos espaços sociopolíticos, chama-se para o texto a reflexão sobre os conceitos de civilização, barbárie e justiça, em seus prismas filosófico e sociológico. 


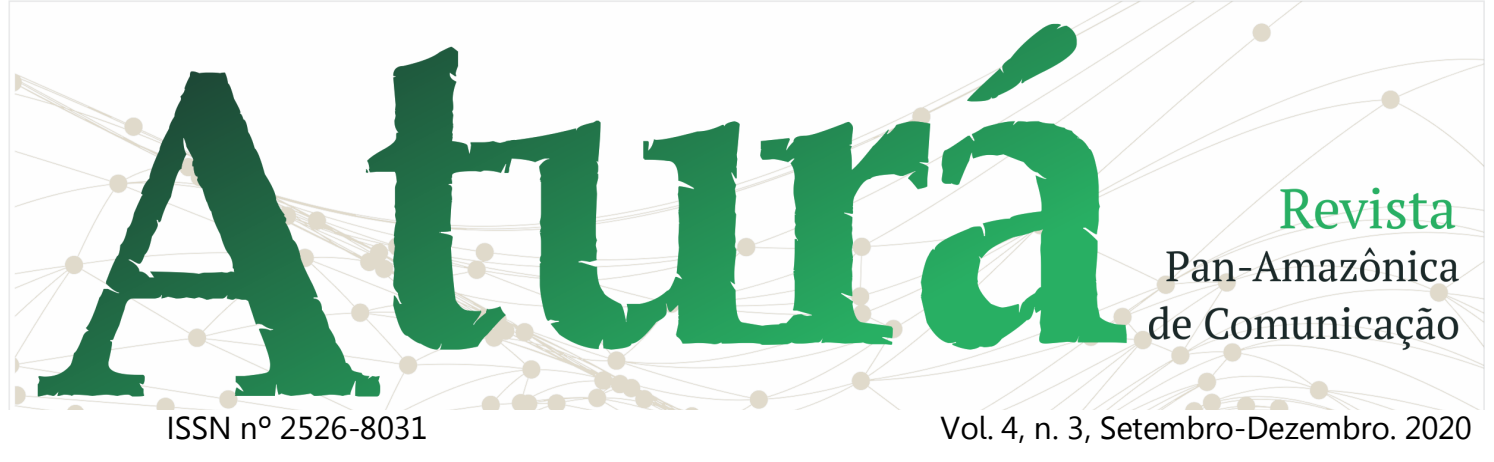

Para a realização desse intento, trabalhou-se com o mapeamento das produções acadêmicas, de distintos campos do conhecimento, que podem auxiliar na análise dos aspectos e dimensões da problemática levantada. Optou-se por estabelecer interlocução com as reflexões de $A$. Héller e Ferenc Féher, Axel Honneth, e Nancy Fraser, além das contribuições de E. Hobsbawm, Jessé de Souza e Alex Pizzio. Em suma, uma questão pode-se ser estabelecida frente ao quadro situacional observado e pelas leituras realizadas: como trabalhar para a difusão da justiça frente a sociedade que vive sob o espectro da incivilidade e barbárie, a partir da associação das reflexões específicas de Axel Honneth e Nancy Fraser?

O texto está organizado em três partes distintas, nas quais buscou-se, mesmo que de maneira breve, trabalhar conceitos basilares para auxiliar no entendimento proposto. A primeira parte abordou os aspectos etimológicos, filosóficos e sociológicos no binômio civilização-barbárie e trazendo-os para o

momento atual vivido. A segunda parte tratou do conceito de justiça, embora com inúmeras possibilidades de abordagem, ateve-se a filósofos húngaros Agnes Heller e F. Féher. Na terceira parte, apresentou-se as abordagens de Nancy Fraser e Axel Honneth, por fim, na parte final, o intento de responder à questão levantada inicialmente.

\section{Entendimento básico sobre os conceitos civilização e barbárie}

Era comum escutar, outrora, que determinadas atuações nos embates no contexto jurídico em prol da defesa dos direitos dos grupos minoritários e explorados na sociedade brasileira era algo injusto e tendencioso, porque somente visava minorias específicas e não visavam o totus social. Comentários sobre isso ocorriam em rodas de bate-papo informais, pequenas notas de jornalistas confessadamente de pensamento conservantista e reacionário às mudanças sociocomportamentais e de defesa dos direitos fundamentais de todas as pessoas - de acordo com os preceitos 


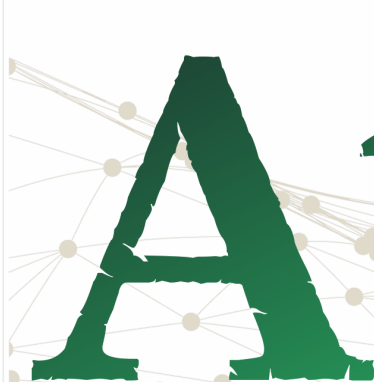

ISSN n² 2526-8031
Revista

Pan-Amazônica

de Comunicação

Vol. 4, n. 3, Setembro-Dezembro. 2020

magnos constitucionais.

Os comentários e suas respectivas ressonâncias tinham uma certa abrangência de público ou audiência, ficavam restritos a um nicho específico. Isso veio a se modificar com o desenvolvimento tecnológico informático por meio das redes sociais e da internet. Muito embora se viva em um país de flagrante desigualdade social (SOUZA, 2004) existe essa ilusão de que a brecha digital foi sanada pela oportunidade de consumo e acesso aos dispositivos e aplicativos tecnológicos, como se ocorresse a tão almejada correção da contradição da sociedade dividida em classes sob os princípios da exploração do sistema capitalista.

A ilusão pode ser verificada à profusão de textos e vozes - de grupos familiares, laborais, de interesse cultural e artístico, agremiações políticas, etc. - que a tudo opinam e ajuízam, dando outra dimensão aos fatos e acontecimentos, em especial aos jurídicos. A ilusão da participação coletiva, de forma global, engendra as ideias de incivilidade e barbárie no seio da própria sociedade que se diz democrática.

Nesse espaço virtual, podendo ser considerado um turbilhão de opiniões de ajuizamentos, discussões polarizadas sobre aspectos ideológicos dos grupos que se confrontam na arena do poder são amplificados em argumentações acusatórias e apelativas, traz-se como exemplo as manifestações de violência contra as mulheres e os crimes de feminicídio que são vistos como uma tentativa de distorcer a honra dos homens vilipendiados pela traição conjugal ou provocados pela exibição da sensualidade feminina pública; sentenças diferenciadas entre réus brancos e pobres são assumidas com "naturalidade" porque a população preta possuiria indelével propensão à criminalidade. Vozes no espaço digital e presentes em manifestações políticas públicas ora pedem a derrocada do Supremo Tribunal Federal de forma violenta, defendem ou atacam golpes militares ora pedem uso indiscriminado de armas e mudança para um código penal mais rigoroso, próximo 


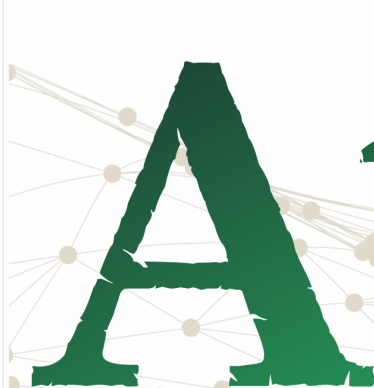

ISSN n² 2526-8031
Revista

Pan-Amazônica

de Comunicação

Vol. 4, n. 3, Setembro-Dezembro. 2020

a um texto radical de cunho religioso extremista.

A incivilidade faz-se presente no cenário. Mas antes dela é importante recuperar o significado de civilização para não se incorrer no que essas estranhas vozes estão pedindo como possível evolução civilizatória: hábitos monárquicos, educação requintada e erudita, modelos estereotipados de heróis militares e princesas recatadas.

O termo civilização é algo de recente uso para os falantes da língua portuguesa, de acordo com historiadores, etnólogos e filólogos (BRAUDEL, 1989; AZEVEDO， 2003; CUNHA, 1982; MACHADO, 1990). Sua criação nas línguas da Europa ocidental ocorre na segunda metade do século XVIII. A ilusão etimológica dada em determinados textos jurídicos sobre a derivação de civilização do adjetivo civitas (das qualidades daquele que possui alma nobre e elevada, também estando associado ao governo da cidade) e relacionado à vida na urbe (na cidade) carece de maiores detalhes cronológicos, como por exemplo, que esta última associação civitas-urbanidade foi elaborada no século XIII e, que o verbo civilizar, o adjetivo civil, o substantivo civilidade possibilitam somente no século XVIII a conotação de civilis. Mesmo que termo francês civilité tenha sido utilizado por Erasmo de Roterdam, em 1530, em seu livro De civilitate morum puerilum Da civilidade em crianças, destinado à educação infantil. O que é interessante perceber é o termo civilitas que saiu do âmbito de urbanidade e ganhou significado de polidez, afabilidade, cortesia e refinamento.

A civilidade está no domínio das classes privilegiadas nas cidades europeias, trazendo seu contraponto no incivilizado, enquanto algo bruto, sem comportamento, sem conduta e pertencente ao campo. Ser e viver na civilização obedeceria, então, a um código de conduta para as cortes e posteriormente, à burguesia no poder.

No âmbito jurídico, o conceito de civilização ganha materialidade no século XVIII, a partir do ideário iluminista da 


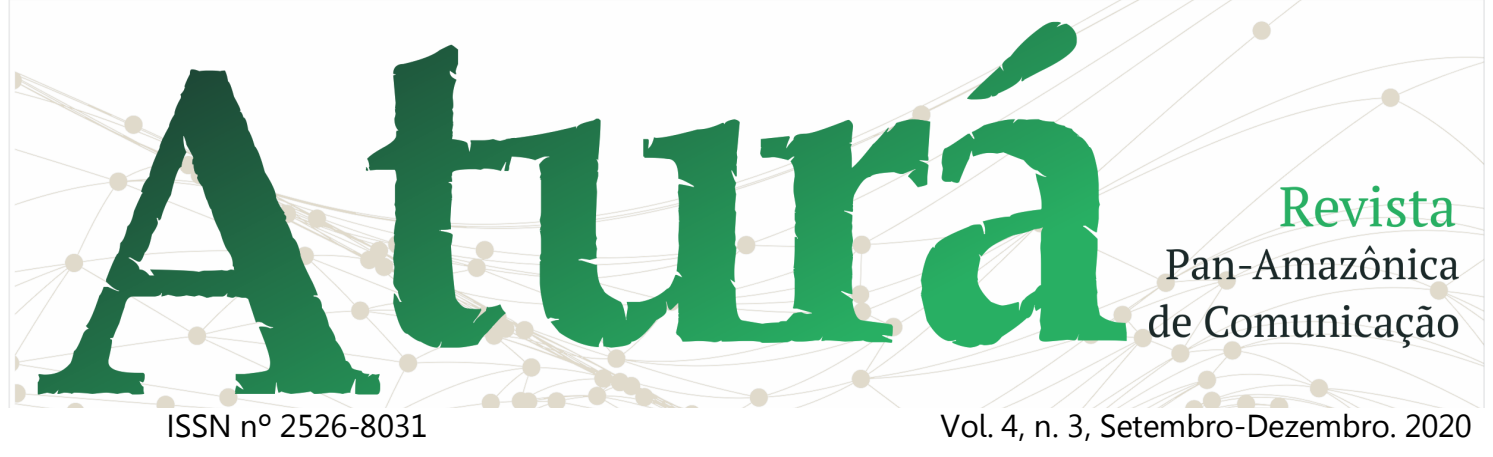

Revolução Francesa (STAROBINSKI, 2001). Antes considerada algo dos nobres, naquele instante teve seu sentido ressemantizado, isto é, foi apropriado pelos grupos pós-revolucionários para o novo Homem em surgimento. Mas é um termo perigoso, pois toda sociedade considerada civilizada terá um outro para referendar sua condição evolutiva de desenvolvimento. $\mathrm{O}$ outro será o bárbaro.

Nos primórdios da revolução industrial inglesa, o termo foi agregado a ideia de progresso, ou seja, uma sociedade civil somente o será se aprender a conjugar sua história com o desenvolvimento técnico e científico. Esse ideário perpassa o século XIX. De acordo com Starobinski (2001), palavras com o sufixo "action" foram agregadas em palavras-chave no cenário político e social para designar a ideia de ação, de movimento, de uma máquina em funcionamento: municipalização, democratização e civilização. Trazem a ideia de movimento e de conformação dos indivíduos em seus quadros, normas e dinâmicas de funcionamento.
A civilização seria a perfeita tradução de um povo, o europeu, em um estágio superior da trilha do conhecimento e domínio do mundo. Contudo, embora tenha sido traduzida para as línguas italiana (civilizzazione), espanhola (civilización), alemã (zivilization) no século XIX, relacionando o termo aos espaços da cidade (urbanização), nas colônias de exploração na América, África e Ásia ocorreu processo inverso daquele que se presumia na Europa. Civilização era o espaço da metrópole, os colonizadores traziam a marca da superioridade e o início da subalternidade e escravidão para com as populações nativas e o imenso contingente de pessoas vítima do tráfico de escravos.

Nesse sentido, ao se perguntar sobre a utilização do termo em língua portuguesa e, em especial, no Brasil, pode-se averiguar que seu uso ocorreu a partir de meados do século XIX, importado da língua francesa, em 1831 na quarta edição do Diccionário da Lingua Portuguesa de Antonio de Moraes 


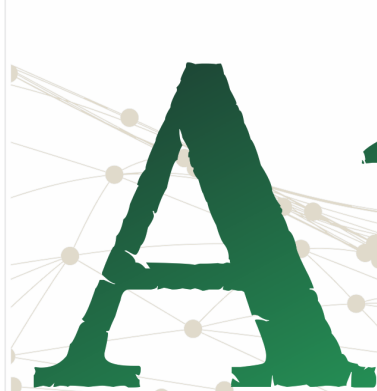

ISSN n² 2526-8031
Revista

Pan-Amazônica

de Comunicação

Vol. 4, n. 3, Setembro-Dezembro. 2020

Silva. Nas edições seguintes, o termo tanto trazia a ação tornar civil, fazer respeitar a ordem social baseada na lei e naquilo que era considerado urbano, como também referente aos aspectos de sociabilidade e organização social, cultural e política de uma determinada população. No Brasil, o Dicionário Moraes foi editado pelo Instituto Histórico e Geográfico Brasileiro, assumindo a civilização tanto como urbe para espaço de progresso como o cultivar atos das virtudes sociais, manutenção de bons costumes. E os não civilizados são os povos nativos em suas diferentes nações e as populações negras do continente africano vivendo sob escravidão. O agente civilizador naquele momento histórico era o Estado Imperial.

Frisa-se que o termo civilização, em sua acepção atualmente utilizada é iluminista (CONDECERT, 1968 apud SILVA, p. 02, online), mesmo que os agentes pós-revolucionários também tenham utilizado da violência para evidenciar sobre os que era contra o novo regime republicano; dessa maneira, o bárbaro pode ser assumido como aquele que se posiciona contra o regime. É inversão de sentidos, pois a barbárie tem herança, inicialmente, da sociedade do império romano que presumia como rudimentar, violento e não humano todo povo diferente de si mesmo.

Vale a pena ressaltar as considerações de Francis Wolff (2004) sobre como o "eu" pertencente a um grupo qualifica o "outro" como diferente e bárbaro, ou seja, "a fim de defender sua própria e única concepção de civilização", não levando em conta e muito menos respeitando as diferenças, distinções, complexidades e singularidades identitarias e representacionais. Com isso, o "outro" - com seu grupo, comunidade ou sociedade - é o sujeito daquilo que se aprende a considerar como barbárie, isto é, algum ato violento, agressivo, diverso daquilo que é civilizado.

De acordo com Wolff (2004, p. 21) considera-se que os civilizados admitem desempenhar um papel libertador em sua relação com os outros diferentes, por estes últimos poderiam serem libertos de 


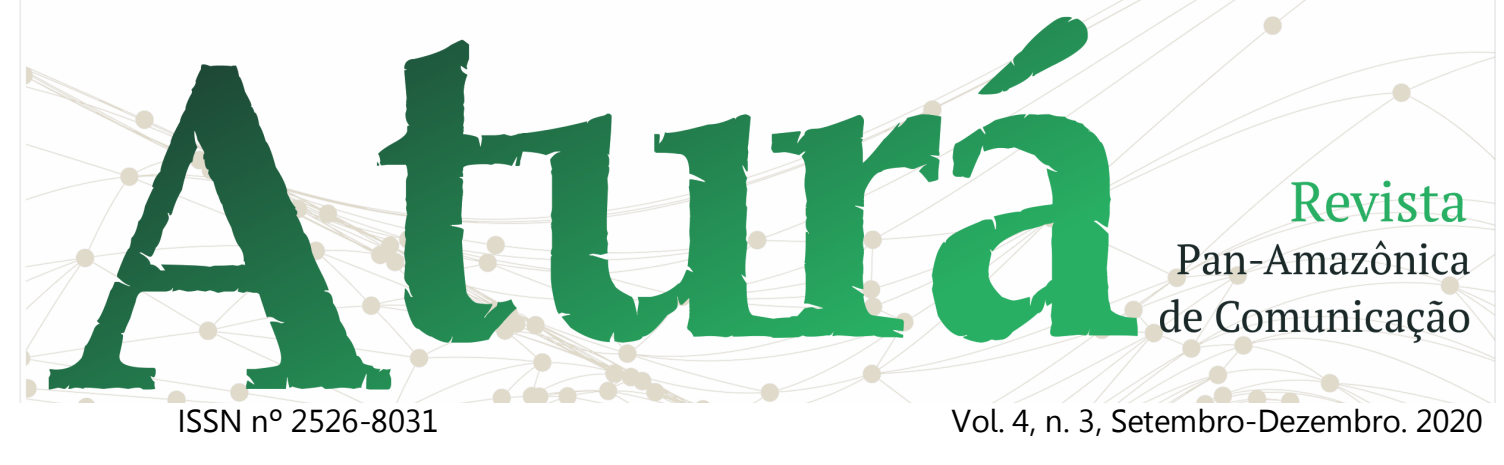

todos os costumes selvagens e ignorantes, também na esfera intelectual e política.

Os bárbaros são insensíveis ao saber ou à beleza pura, não respeitam o valor destes ou não compreendem seu sentido, só reconhecem valor no útil, na satisfação das necessidades vitais ou dos prazeres grosseiros. O bárbaro, portanto, é aquele que pilha igrejas para fundir o outro que nelas encontra, que queimam os livros ou destroi as estátuas. Para alguns, é simplesmente a civilização Disneylândia e McDonald's, pela imagem que passa da diversão ou da gastronomia. (WOLFF, 2004, p. 22)

Ao trazer o questionamento para os tempos atuais, Wolff (2004) demanda:

Quem é civilizado, e quem é bárbaro [...] É igualmente difícil pensar assim, mesmo porque quando um país, uma sociedade ou uma cultura se identifica à civilização, qualificando como bárbaros seus adversários, quase sempre é para justificar iniciativas imperialistas menos recomendáveis. (p.4)

Para o historiador Eric Hobsbawm (2013), a barbárie traz consigo dois significados que sempre deve ser observado em sua manifestação:

Primeiro, a ruptura e colapso dos sistemas de regras e comportamento moral pelos quais todas as sociedades controlam as relações entre seus membros e, em menor extensão, entre seus membros e os de outras sociedades. Em segundo lugar, ou seja, mais especificamente, a reversão do que poderíamos chamar de projeto do Iluminismo do século XVIII, a saber, o estabelecimento de um sistema universal de tais regras e normas de comportamento moral, corporificado nas instituições. (p.347-348)

A relação civilização-barbárie transmuta-se na periodização das sociedades humanas. $\mathrm{Na}$ atualidade, referir-se ao barbarismo é o mesmo que associar irracionalidade, brutalidade, violência, assassinato, extermínio e morte para uma sociedade que se considera democrática e evoluída. A exploração de um indivíduo para com o outro, por meio de um sistema de produção predatório não é concebido como tal. E vive-se nesse pêndulo entre o civilizado (moral) e o incivilizado (imoral), o polido (urbano) e o rude (rural) perpassado nas instituições laicas e religiosas nos últimos dois séculos.

Frente a tudo isso, ocorre um movimento de ressignificação da relação civilização-barbárie novamente, algo que necessita ser analisado, também, por outras áreas do conhecimento. No âmbito jurídico, a sociedade está consolidada em sua base legal, mesmo com suas contradições inerentes mas 


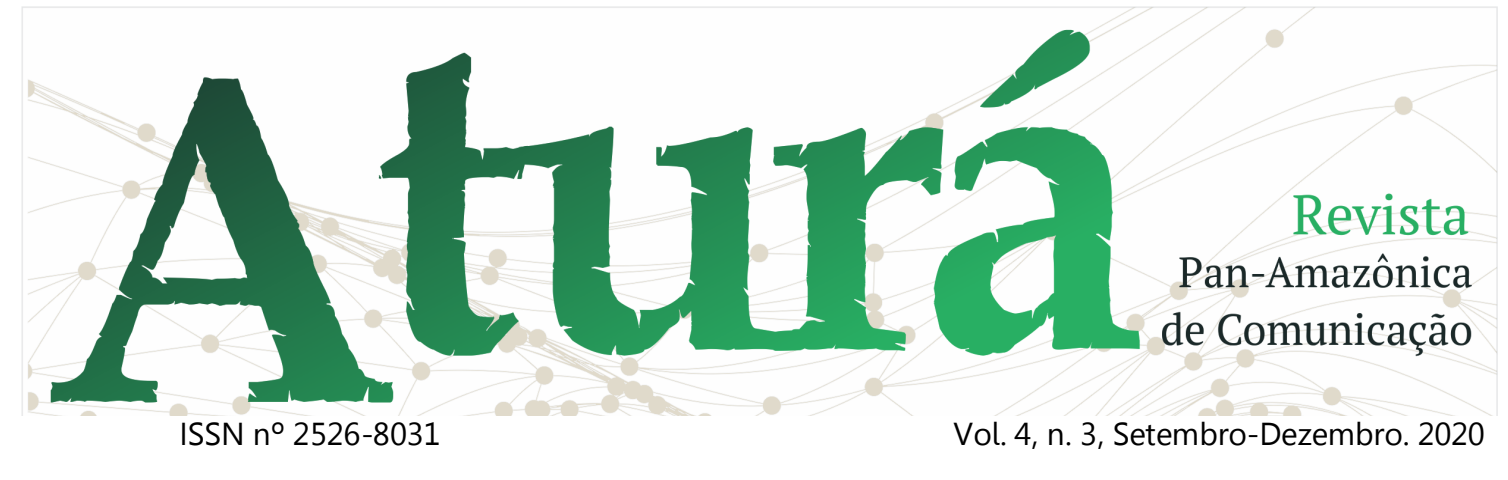

com dispositivos legais para defender e clivagens e novas formas de diferenciação social.

proteger a dignidade das pessoas, respeitar as diferenças e a diversidade de pessoas, mas as tendências políticas ideológicas conservadoras radicais vem abrindo espaços junto à população contra as conquistas democráticas e aos marcos legais civilizatórios.

Nos idos de 2013, o pesquisador Alex Pizzio sinalizava com respeito à sociedade nacional:

Considerando os avanços observados nas últimas décadas na sociedade brasileira, constata-se que ela se encontra em um momento de mudanças e de conformação a novas situações na estrutura social. Pode-se definir o momento como complexo, caracterizado por novas clivagens que transpassam as tradicionais estruturas de classe, desfazendo e criando novas identidades e revelando uma dinâmica societária [...]. Fala-se aqui de novas hierarquias sociais, que se encontram atravessadas por enormes disparidades de renda, de cultura, de valores, mas, também, de acesso a mecanismos de representação e participação política; de diferenças no uso da cidade, nos modos de fixação e mobilidade no espaço urbano e acesso a bens materiais e simbólicos de uma sociedade de consumo pujante, mas também extremamente estratificada e excludente; de diferentes e muito desiguais formas de integração em um mercado que se altera em ritmo acelerado, desestabilizando posições consolidadas, desfazendo hierarquias ocupacionais tradicionais e criando novas

Existe possibilidade de risco ao se defender a democracia e a justiça por si mesmas, como baluartes pétreos da sociedade, mais uma vez, recorre-se a Pizzio (2013, p. 8) para recordar que:

"[...] nada tem valor por si mesmo, os valores são, em essência, conferidos por juízos humanos. Assim, a importância de cada coisa depende do lugar que ocupa em uma série de outros objetos complementares. Em vez de tomar um objeto isoladamente para obter a informação que ele transmite, torna-se mais elucidativo buscar capturar todo o espaço de significação. Em outras palavras, deve-se investigar a realidade dentro do ambiente cultural que the é constitutivo".

Com essa consideração, trabalhase na parte a seguir sobre justamente a possibilidade de se situar para este contexto diferente no Brasil uma concepção de justiça.

\section{Acercamento teórico sobre a justiça}

Nessa encruzilhada entre novos grupos que propõem ser opção de mão única para interpretar, justificar e governar a sociedade brasileira, traz-se a contribuição pensadores húngaros Agnes 


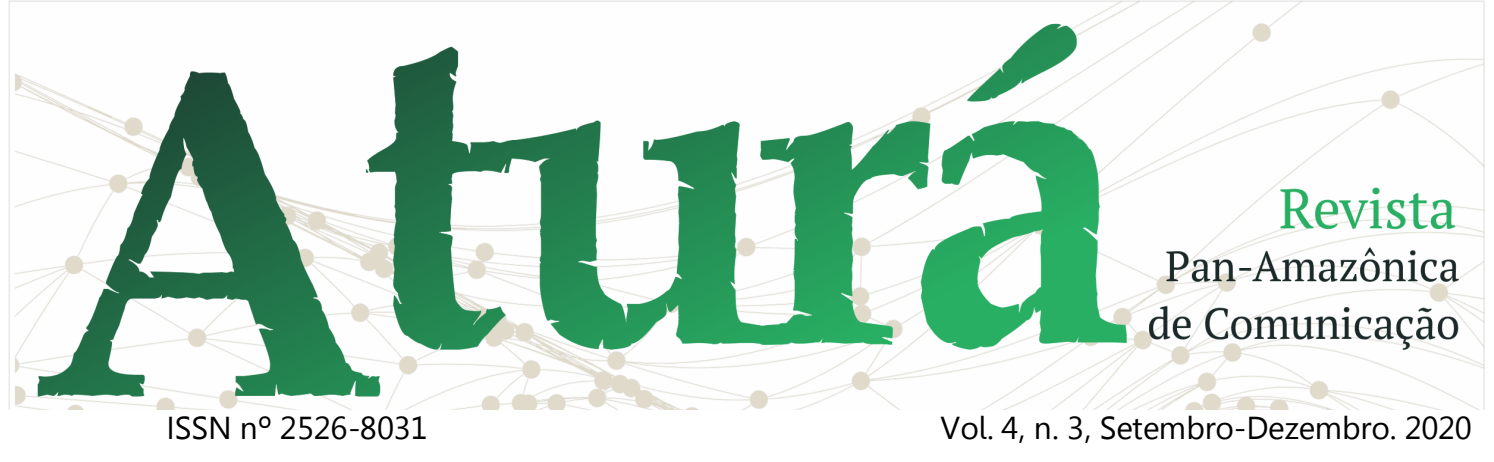

Heller (1929-2019) e Ferenc Féher (19331994), a partir da obra "A condição pósmoderna".

Esses dois estudiosos têm em suas biografias relatos vivos sobre a ascensão do marxismo leninismo e a força do stalinismo nos países do leste europeu, dominados pelo totalitarismo do regime socialista, vivenciaram a crise do marxismo e a ebulição nas discussões filosóficas, sociológicas e políticas com a queda do muro de Berlim e dissolução da União das Repúblicas Socialistas Soviéticas (URSS), estabeleceram-se nos países capitalistas como Estados Unidos e Austrália entendendo a partir de dentro o funcionamento do sistema de produção no mundo ocidental; acompanharam, em especial Agnes Heller o ressurgimento religioso, os micro discursos sobre narrativas de vida e história dos indivíduos e sociedades - localizada e desconectada das grandes narrativas do Iluminismo - e o questionamento sobre o que seria a justiça em meio a esse quadro conjuntural mundial de mudanças.

Heller assume que os indivíduos na vida cotidiana abrem mãos das narrativas grandiosas dos sujeitos, a partir daquilo que foi vivido na Europa, com a ascensão do nazismo e extermínio de milhões de pessoas nos campos de concentração. A grande narrativa trouxe uma estrutura de dominação sofisticada para as sociedades, com isso, o pensamento das pessoas na vida cotidiana torna-se algo econômico, no sentido de não mais elucubrar com questões filosóficas, metafísicas e eruditas hegemônicas, mas com pluralidade de espaços e temporalidades. A narrativa dos seres humanos coletivos dá lugar a microrelatos localizados e individuais.

Para esses tempos diferenciados, Heller e Féher (1998) trazem, de forma didática, os princípios da justiça social. Para eles "a justiça é uma virtude fria, pois requer imparcialidade (1998, p.175) diante da diversidade dos seres humanos:

As personalidades humanas são, sem dúvida, únicas, e portanto nenhuma pessoa humana é, como um todo, igual a qualquer outra pessoa humana; as pessoas em sua totalidade são simplesmente diferentes, e como tal imensuráveis. Contudo, se comparamos seres humanos que pertencem ao mesmo aglomerado, não mais os estamos 


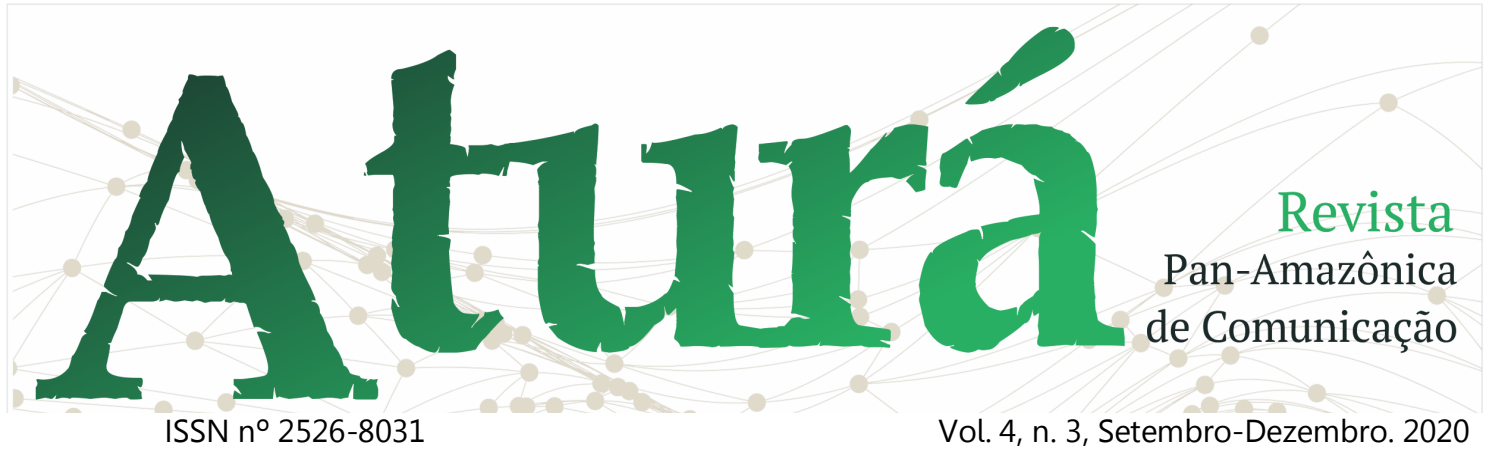

comparando como totalidades, mas apenas da perspectiva de uma norma ou regra, quer dizer, apenas num aspecto. Assim, se afirmamos, no espírito da Declaração dos Direitos Humanos, que todos os seres humanos nascem iguais, certamente não queremos dizer que são todos semelhantes. $\mathrm{O}$ que queremos dizer é antes que todos os seres humanos nascem como membros do aglomerado universal chamado humanidade, e que merecem igual reconhecimento de sua condição humana em virtude de pertencerem ao mesmo aglomerado (universal). Igualdade não é uma substância; tanto igualdade quanto desigualdade são constituídas por normas e regras, e só por elas. (HELLER \& FËHER, 1998, p.174)

Para lidar com essa humanidade diversa, a justiça possui aspectos gerais e abstratos para abarcar sua vasta tipificação, pois envolve de maneira concreta indivíduos e coletividades. Heller e Féher (1998) adotam a fórmula:

"As normas e regras que constituem um aglomerado humano devem ser aplicadas consistente e continuamente a cada um e todos os membros desse aglomerado." Vamos chamar essa fórmula de conceito formal de justiça. A fórmula pode ser aplicada a todos os casos concretos de justiça. Somos justos se agimos de acordo com a prescrição contida na fórmula. Ao contrário, podem dizer que agimos de modo injusto sempre que (a) aplicamos normas e regras inconsistentemente, (b) as aplicamos de modo descontínuo ou (c) aplicamos uma norma ou regra diferente daquela que o aglomerado humano constitui para seus membros. (p.173)

Assim caracterizam os atos considerados justos e injustos:

Há muitos tipos diferentes de atos justos e injustos. Há atos de julgamento, atos de distribuição, atos que concedem ou negam alguma coisa, atos de premiação e castigo, e muitos outros tipos. Contudo, só se pode atribuir justiça ou injustiça a uma ação executada segundo regras e normas. Segue-se disso que a natureza não pode ser justa ou injusta, embora às vezes, metaforicamente, lhe estendamos o uso desses termos. Também se segue disso que os sentimentos em si não podem ser chamados de justos ou injustos. Finalmente, segue- se disso que as ações só podem ser justas ou injustas se puderem ser comparadas e, incidentalmente, classificadas. É por isso que igualda de e desigualdade são os valores constitutivos da justiça. (HELLER \& FËHER, 1998, p.174)

Frente aos que defendem a possibilidade da incivilidade como desobediência à sociedade civil constituída, ostentando discursos preconizadores de violência e existência da barbárie naturalizada, como também para os que defendem a sociedade democrática mas não se questionam sobre as desigualdades sociais e exploração e alienação da mão de obra de trabalho (a verdadeira barbárie do sistema capitalismo) - parecendo estar congelados numa narrativa histórica superada - é preciso recuperar a ideia de 


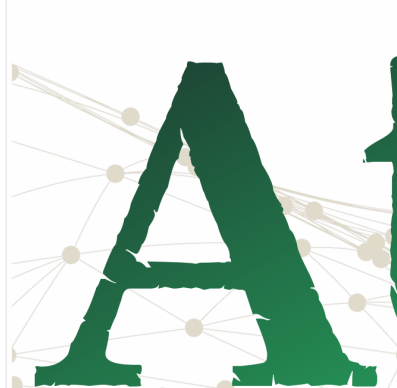

ISSN n² 2526-8031
Revista

Pan-Amazônica

de Comunicação que ser justo é uma virtude moral, o contrário é exemplo de deficiência. É importante o seguir as normas e as regras para manter a proposta universal de que somos humanos em pensamentos e nas experiências. De acordo com Heller e Féher (1998, p. 175) "ser justo é uma virtude moral, ser injusto é uma séria deficiência moral, independente de se as normas e regras que a pessoa aplica consistente e continuamente, ou deixa de aplicar adequadamente, tem alguma coisa a ver com questões morais".

Como estabelecer os princípios da justiça para que as ações na sociedade brasileira, enquanto mundo social e conflituoso, não resvalem para a injustiça sobretudo num país que é fortemente marcado pela desigualdade da distribuição dos bens materiais, convive com extremos avanços tecnológicos, no qual se pode conquistar espaços de vezfala-atuação para minorias historicamente invisíveis e agora, tem no poder político central discursos e práticas cotejadoras dos conservadores de extrema direita internacional, com uma agenda expressamente neoliberal?

A desigualdade material de bens é reconhecida e foi incluída discursivamente e por representação simbólica nas agendas dos movimentos que objetivam ser reconhecidos socialmente por suas identidades e diferenças. Como aplicar os conceitos de (re)distribuição, reconhecimento e participação para defender as conquistas estabelecidas na sociedade nacional frente a ameaça de tendências conservadoras?

\section{As contribuições teóricas reflexivas de Nancy Fraser e Axel Honneth}

Uma questão deve ser esclarecida desde o início dessa reflexão, isto é, sobre as intencionalidades de trazer Nancy Fraser e Axel Honneth para a discussão proposta. Ambos pesquisadores são pouco conhecidos, ainda, no panorama regional dos estudos do direito e dos intentos de ações interdisciplinares para entendimento das teorias da justiça, dos enfoques sobre $\mathrm{o}$ entendimento $\mathrm{e}$ mediação dos conflitos no contexto social 


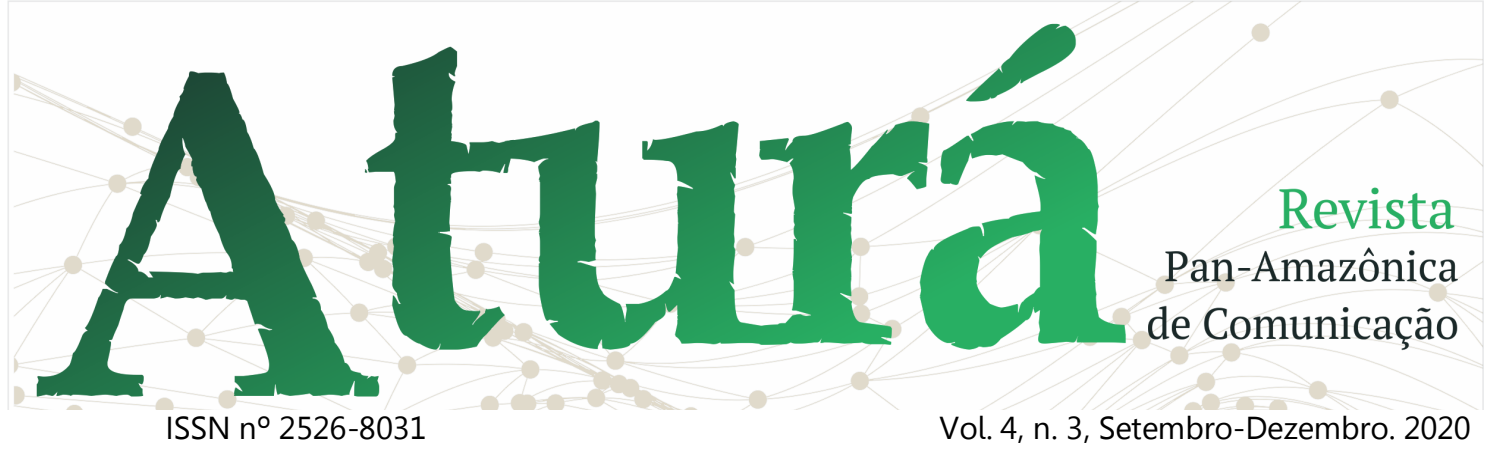

regional.

Inicia-se, uma apresentação de ambos por seus pontos de convergência, ou seja, a estadunidense Nancy Fraser (1947) e o alemão Axel Honneth (1949) têm formação acadêmica em filosofia, trafegando pelas ciências sociais e ciências políticas, sendo considerados como representantes das reflexões contemporâneas da teoria crítica e em parte, continuadores das proposições estabelecidas por Max Horkheimer (18951973) e Theodor Adorno (1903-1969), além de filósofo e sociológico Jurgen Habermas (1929). Em muito Fraser e Honneth trazem as influências da Escola de Frankfurt como também superaram determinados corolários ao longo dos anos.

Ambos possuem preocupações semelhantes no tocante às dimensões das teorias da justiça que propõem. Fraser e Honneth, embora em continentes diferentes, pertencem à geração nascida no mundo pós-Segunda Guerra Mundial, tiveram infância, adolescência e aprendizagem acadêmica no momento histórico de extrema polarização políticoideológica e acompanharam as críticas aos modos de produção capitalista e socialista, assistindo e participando dos movimentos sociais e políticos que engendraram as pautas do feminismo, das lutas antirracistas, além de outras questões relevantes para a segunda metade do século $X X$ até o presente momento.

\subsection{A perspectiva da justiça em Nancy Fraser}

Uma questão que persegue determinados espaços de reflexão teórica na área do direito recai sobre a análise dos fatos e visualização de aspectos de equilíbrio justo para os indivíduos a partir da perspectiva de classe social ou da identidade, da marca da subjetividade do ser oriundo de um determinado locus cultural e étnico. Em Fraser já se pode perceber que a justiça se alcança quando se permite conceber o direito que todos têm para participar paritariamente da vida social.

Enquanto uma pesquisadora que traz as pautas feministas em sua prática 


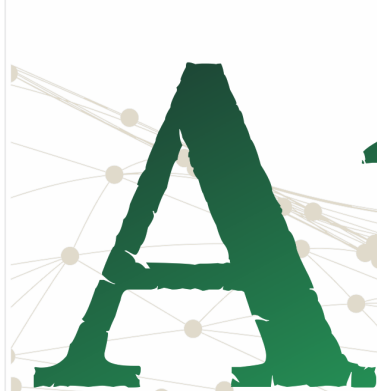

ISSN n² 2526-8031
Revista

Pan-Amazônica

de Comunicação política cidadã, ela supera a questão somente do reconhecimento, pois podese reconhecer e colocar um ponto final, aplicando-se de maneira generalista as normas. Fraser traz como imperativo a importância de se reconhecer o papel das identidades e da dominação cultural. Além da dominação econômica os grupos são colocados numa condição de subalternidade. Nisso existindo uma dupla dominação a ser enfrentada politicamente pelos intelectuais e pessoas engajadas em ações em prol de uma sociedade digna e justa.

O cerne da proposição de Fraser encontra-se no respeito à identidade cultural dos grupos, pois não basta apenas ser reconhecido como grupo porque existem reivindicações que abarcam os aspectos da igualdade socioeconômica. É fundamental que a justiça tenha uma noção que abarque as reivindicações que possuem defesa nos domínios da igualdade social e daquelas outras presentes na questão das diferenças.

$$
\text { Re(distribuir) implica dar o justo }
$$

valor para manter o equilíbrio da moral dos costumes contextualizados, reconhecer encontra-se num domínio mais amplo, isto é, universal no sentido de estabelecer $\mathrm{o}$ respeito em todos âmbitos e instâncias das sociedades no planeta. Fraser, estrategicamente, alia as reivindicações dos grupos por reconhecimento como demandas de justiça, que por sua vez não descarta a importância da redistribuição (FRASER, 2009).

Para o enfrentamento das relações de subalternidade e subordinação os indivíduos devem ter o direito de participação na vida social. Frase destaca a categoria de status social para dar visibilidade os sujeitos originários de grupos identitários organizados politicamente participante da vida social política. Aqui não se trata do status social como se fosse o glamour das elites em colunas sociais de jornais latinoamericanos. Status é equiparação pelo reconhecimento de se estar no mesmo nível para discutir e tomar decisões (FRASER, 2009). 


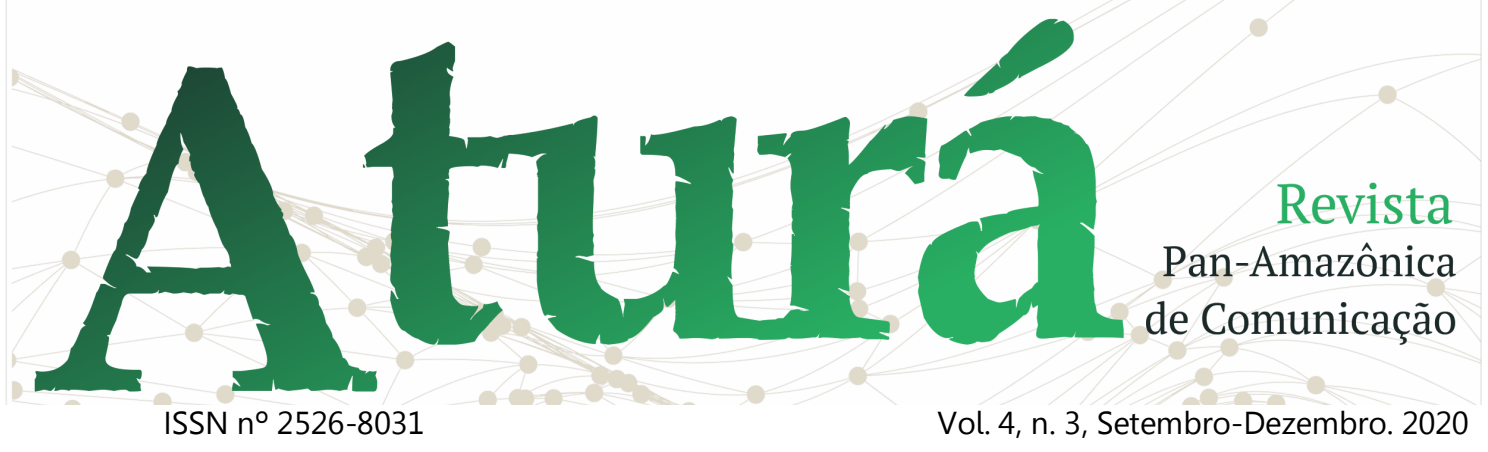

"Uma vez que as demandas já não se endereçam exclusivamente aos Estados nacionais e também não são debatidas somente pelos públicos nacionais, os reivindicantes não se focam mais apenas nas relações entre cidadãos. Assim, a gramática do argumento se alterou. Seja uma questão de redistribuição seja de reconhecimento, as disputas, que antes se focalizavam exclusivamente sobre o que era devido aos membros da comunidade como uma questão de justiça, agora, rapidamente, se transformam em disputas acerca de quem deve contar como um membro e qual é a comunidade relevante. Não apenas o "o que", mas também "quem" está em disputa. (FRASER, 2009, p. 15-16)

Praticar a justiça, então, exige o exercício da redistribuição associado ao reconhecimento. Por exemplo, por ser objeto de estudo da autora deste artigo as manifestações de racismo na esfera judiciária, permite-se trazer à baila, a necessidade de reconhecimento da privação econômica e o reconhecimento do desrespeito cultural entrelaçados para com réus pardos e pretos no sistema judiciário. É importante perceber e captar as nuances dessas duas dimensões, até mesmo para não se cair na armadilha de tentar resolver ambas simultaneamente. Primeiro deve-se situar num quadro conceitual que analise a existência de ambas, para depois partir-se para intentos de operacionalização de resolução no âmbito político, mas reconhecendo, conforme Fraser aponta a necessidade de distinção conceitual entre a injustiça econômica (com forte enraizamento econômico-político na sociedade e produtora da desigualdade material) e injustiça cultural (perceptível no ocultamento/naturalização dos preconceitos e no desrespeito social) para melhor atuar com esses dilemas na cena política.

Insistirei em distinguir analiticamente injustiça econômica e injustiça cultural, em que pese seu mútuo entrelaçamento. O remédio para a injustiça econômica é alguma espécie de reestruturação político-econômica. Pode envolver redistribuição de renda, reorganização da divisão do trabalho, controles democráticos do investimento ou a transformação de outras estruturas econômicas básicas. Embora esses vários remédios difiram significativamente entre si, doravante vou me referir a todo esse grupo pelo termo genérico "redistribuição". O remédio para a injustiça cultural, em contraste, é alguma espécie de mudança cultural ou simbólica. Pode envolver a revalorização das identidades desrespeitadas e dos produtos culturais dos grupos difamados. Pode envolver, também, o reconhecimento e a valorização positiva da diversidade cultural. Mais radicalmente ainda, pode envolver uma transformação abrangente dos padrões sociais de representação, interpretação e comunicação, de modo a transformar o 


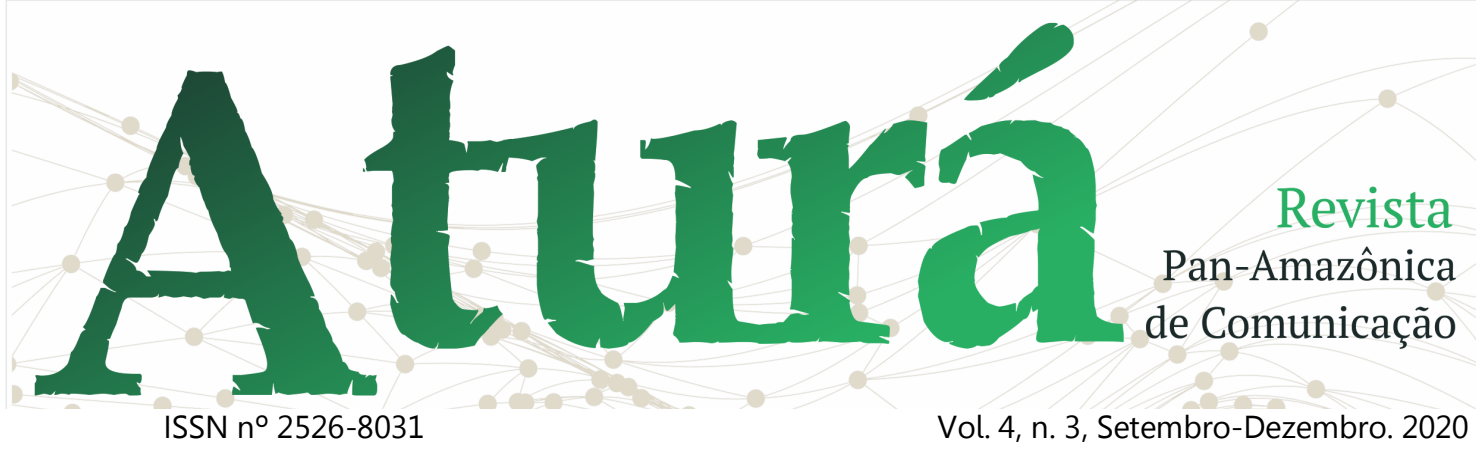

sentido do eu de todas as pessoas. Embora esses remédios difiram significativamente entre si, doravante vou me referir a todo esse grupo pelo termo genérico "reconhecimento. (FRASER, 2006, p. 232)2.

Um homem e uma mulher, negros, desempregados e moradores nas zonas de exclusão na periferia de Palmas-TO e, estado crescente de pauperização, são representantes de uma grande coletividade que não possui voz e vez pois, na percepção de Fraser, eles são "tipos híbridos", pertencentes a uma classe social explorada e racial culturalmente subalternizados. E no caso, da mulher, a diferença de gênero tornase outro agravante, com uma distribuição encadenada de injustiça. Não se pode fechar os olhos para essas coletividades que ora são bivalentes ora cruzadas, ou

2 Para fins de ordenamento metodológico, este fragmento faz parte do texto que foi traduzido por Júlio Assis Simões (2006). O texto original foi publicado em língua inglesa em duas versões aqui apresentadas: FRASER, Nancy. 2001. "From redistribution to recognition? Dilemmas of justice in a 'postsocialist' age". In: S. Seidman; J. Alexander. (orgs.). 2001. The new social theory reader. Londres: Routledge, pp. 285-293; FRASER, Nancy. 2001. "From redistribution to recognition? Dilemmas of justice in a 'postsocialist' age". New Left Review, 212: 68-93, 1995. seja, não é possível estabelecer um enquadramento único para sua análise e entendimento na realidade.

\subsection{A perspectiva da justiça em Axel Honneth}

O ideal presente de justiça, na perspectiva de Axel Honneth, aproximase dos indivíduos que comunitariamente se auto-realizam enquanto sujeitos. À primeira vista parece um raciocínio de extrema facilidade a ser seguido, mas quem se atreve a percorrer essa senda incorre em erro. Axel Honneth, de acordo com comentadores e estudiosos de sua obra, como também suas marcas discursivas, tem uma herança marcadamente do pensamento hegeliano, em especial, do período denominado de escritos do jovem Hegel.

Para aqueles que lidam com a seara do pensamento filosófico do direito, a título de esclarecimento, seria o mesmo que declarar sobre Hans Kelsen (1881-1973), ou seja que o doutrinador " $x$ " está associado aos escritos do jovem Kelsen e o "y" ao Kelsen em sua fase 


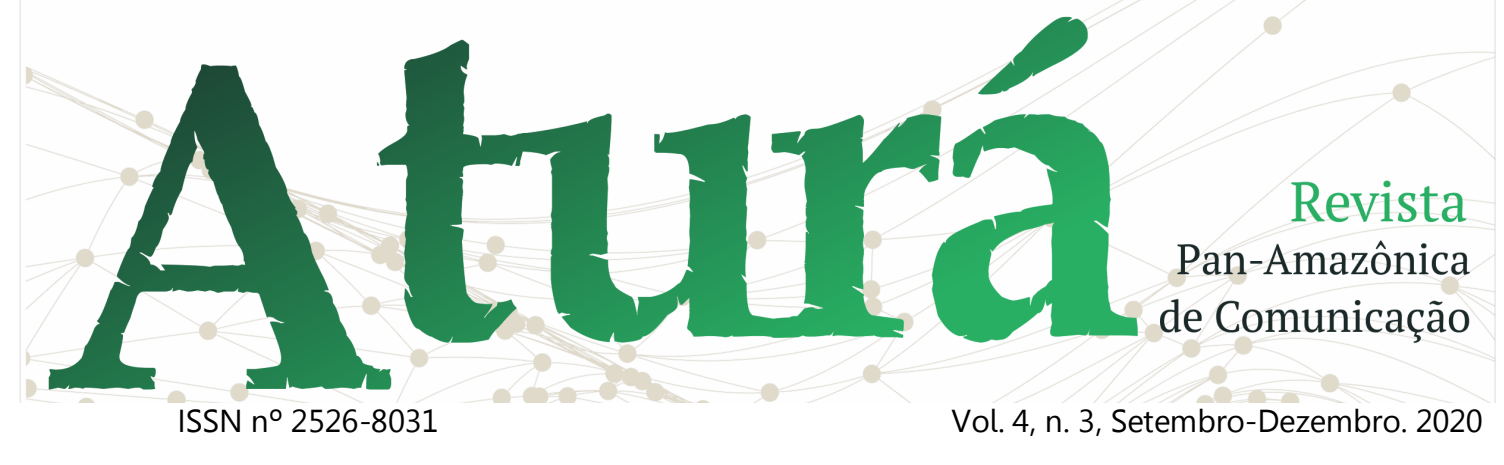

madura.

Estar na seara inicial do filósofo Hegel, em sua fase de juventude, significa refletir sobre a ação humana tendo como guia a preocupação de aceitação intersubjetiva dos sujeitos. autoconservarse. Os seres sociais se tornam pessoas na medida que são aceitos como tal, por meio do reconhecimento de suas qualidades e capacidades. Existe nessa concepção elementos românticos da literatura e religiosos oriundos do Cristianismo. Esse exercício constante possibilita o alastramento do sentimento de comunhão e pertencimento, fazendo com que a relação Eu-Outro revele singularidades e especialidades. $\mathrm{O}$ reconhecimento torna-se um movimento de crescimento dos sujeitos, mas trazendo consigo conflitos para sua realização. (SOUZA, 2000). A ética na vida social está embasada na aceitação.

A estrutura de urna tal relação de reconhecimento recíproco é para Hegel, em todos os casos, a mesma: na medida em que se sabe reconhecido por um outro sujeito em algumas de suas capacidades e propriedades e nisso está reconciliado com ele, um sujeito sempre virá a conhecer, ao mesmo tempo, as partes de sua identidade inconfundível e, desse modo, também estará contraposto ao outro novamente como um particular. Nessa lógica da relação de reconhecimento, porém, Hegel vê inscrita ao mesmo tempo urna dinâmica interna que the permite ainda dar um segundo passo além do modelo inicial de Fichte: visto que os sujeitos, no quadro de urna relação já estabelecida eticamente, vem sempre a saber algo mais acerca de sua identidade particular, pois trata-se em cada caso até mesmo de urna nova dimensão de seu Eu que veem confirmada, eles abandonam novamente a etapa da eticidade alcançada, também de modo conflituoso, para chegar de certa maneira ao reconhecimento de urna forma mais exigente de individualidade; nesse sentido, o movimento de reconhecimento que subjaz a urna relação ética entre sujeitos consiste num processo de etapas de reconciliação e de conflito ao mesmo tempo, as quais substituem urnas as outras. (HONNETH, 2003, p.47)

Nessa perspectiva de um primeiro movimento dialético, composto pelo reconhecimento-conflito-aceitação, a teoria da justiça em Honneth acaba tendo também essa movimentação, tornando-se algo plural, que leva em conta aspectos afetivos da subjetividade humana e motivacional das ações sociais.

Também nessa perspectiva plural e afetiva, a justiça deve evitar as humilhações e desrespeitos sociais porque estes ameaçam a dimensão da personalidade dos indivíduos. Dessa 


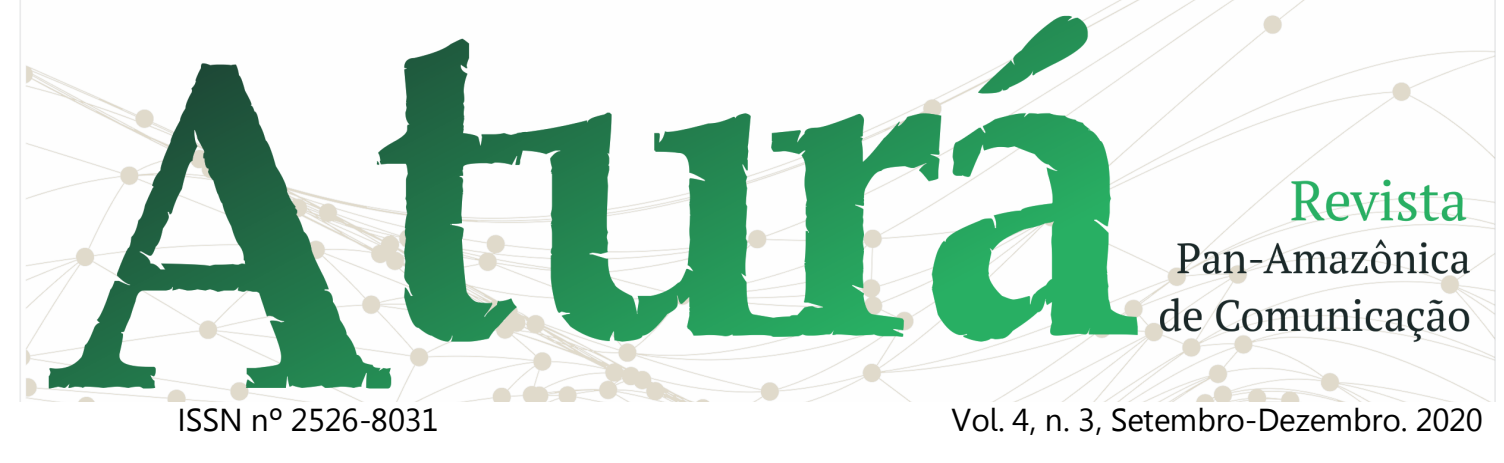

forma, a formação dos indivíduos nos aspectos identitários individuais e grupais e pelas experiências vividas, na participação na esfera pública permitirão o afloramento da personalidade. A justiça se aprende para ele, não vem por meio apenas de códigos doutrinadores.

Para Honneth, três são as esferas que compõem o processo do reconhecimento: a esfera do amor, a esfera da igualdade de tratamento na lei e a esfera da estima social. A esfera do amor está presente na a formação da personalidade dos sujeitos, toda relação de amor é sustentada nessa dinâmica entre dependência e autonomia, da qual depende a confiança do sujeito em si e no mundo (SOBOTTKA, 2015).

Para falar do "amor" não apenas no sentido restrito que o conceito recebe $u$ desde a valorização romântica da relação íntima sexual-", recomenda-se primeiramente um modo de emprego neutro o máximo possível: por relações amorosas devem ser entendidas aqui todas as relações primarias, na medida em que elas consistam em ligações emotivas forres entre poucas pessoas, segundo o padrão de relações eróticas entre dois parceiros, de amizades e de relações pais e filhos. Essa proposta coincide com o emprego que Hegel faz do conceito, no sentido de que nele o "amor" também designa mais do que somente 0

relacionamento sexualmente preenchido entre homem e mulher; é verdade que seus primeiros escritos estão ainda fortemente marcados pela caracterização da ligação emotiva intersexual feita pelo primeiro romantismo, mas nossa interpretação havia mostrado que ele aplica 0 conceito também ao relacionamento afetivo entre pais e filhos no interior da família, por exemplo. Para Hegel, o amor representa a primeira etapa de reconhecimento recíproco, porque em sua efetivação os sujeitos se confirmam mutua- mente na natureza concreta de suas carências, reconhecendo-se assim como seres carentes: na experiência recíproca da dedicação amorosa, dais sujeitos se sabem unidos no fato de serem dependentes, em seu estado carencial, do respectivo outro. (HONNETH, 2003, p.159-160)

A esfera de igualdade de tratamento baseia-se nas relações do direito, por meio de um sistema jurídico representante dos interesses universalizáveis dos membros da sociedade, sem admitir privilégios e hierarquias (HONNETH, 2003). A terceira esfera, da estima social, faz-se presente na possibilidade do reconhecimento e expressão das particularidades de cada um. O que é possível de ser equânime nessa dimensão é a igualdade de oportunidades para realizar diferentes valores sociais (HONNETH, 2003). Ela depende da aceitação dos valores e 


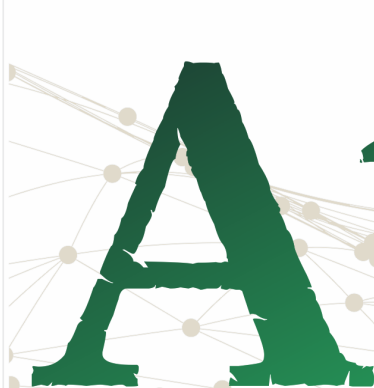

ISSN n² 2526-8031
Revista

Pan-Amazônica

de Comunicação formas de vida particulares; os indivíduos só podem perceber suas capacidades e propriedades positivamente se elas forem estimadas socialmente, se elas forem reconhecidas.

$\mathrm{Na}$ leitura de Honneth percebe-se que $\mathrm{o}$ respeito para com a esfera individual e subjetiva das pessoas, tanto que elas são merecedoras igualitariamente do reconhecimento social, tanto para a formação identitária quanto participação social com paridade. Para ele, o desrespeito impulsionará as lutas sociais quando não permite a realização do bem absoluto das pessoas, esta última como ideal de justiça.

\section{Considerações Finais}

O texto buscou, inicialmente, trazer preocupação sobre o fenômeno do posicionamento conservador, com apelos de argumentos de irracionalidade, que ameaçam a trilha de amadurecimento da democracia brasileira. Embora o texto não se ateve aos aspectos das manifestações dos fenômenos nas mídias sociais digitais, recortou-se para reflexão aspectos teóricos relevantes sobre os termos civilização e barbárie nos dias atuais.

$\mathrm{Na}$ reflexão realizada, teve-se condições para situar a importância de se trazer abordagens teóricas sobre a justiça, diante do risco de concepções particularizadas serem colocadas em prática. Com isso, pode se aventurar por Nancy Fraser e Axel Honneth, por uma própria opção no aprofundamento de estudiosos herdeiros da teórica crítica e de pensadores como Adorno, Horkheimer e Habermas.

Deste modo, brevemente foi levantado como Nancy Fraser e Axel Honneth estabeleceram seus modelos de justiça, entretanto não se ateve aos debates que ambos têm impulsionado ao longo dos últimos anos. Fraser defende a paridade na participação das pessoas na sociedade e Honneth persegue o ideal da auto-realização, apesar de ambos assumirem $\mathrm{o}$ reconhecimento como categoria central e ponto de partida para suas teorias da justiça.

Existem diferenças em suas 


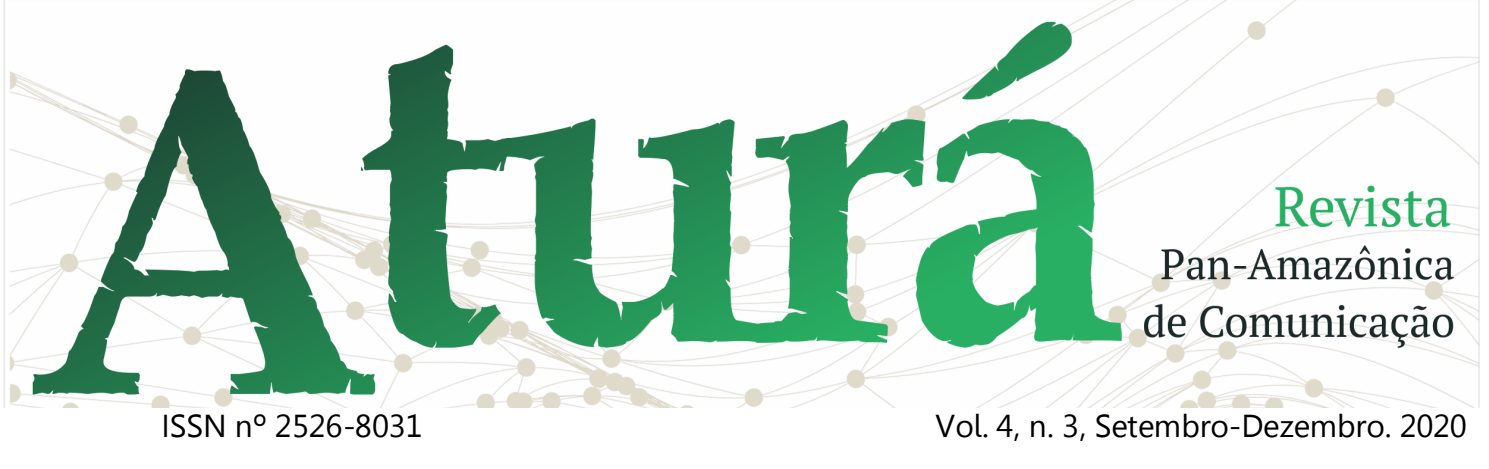

concepções, mas não são irreconciliáveis, o importante é que ambas defendem o bem e o correto na sociedade, o bom e o certo, a relação de reconhecimento do individual, sua originalidade e especificidade com os demais seres para se compreender a totalidade do mundo da vida. Fraser e Honnet trazem a séria e vigorosa preocupação de uma construção mais ampla do conceito de justiça, em meio às particularidades e diferenças. Podem ser abstratos, idealistas, românticos, acadêmicos? Claro que sim, pois com isso, vão auxiliando aos que lidam na vida cotidiana aos enfrentamentos com razoabilidade $\mathrm{e}$ clareza analítica daqueles que preconizam a insegurança, o medo e a barbárie.

\section{Referências}

BRAUDEL, Fernand. Gramática das Civilizações. São Paulo: Martins Fontes, 1989.

AZEVEDO, André Nunes de. Da Monarquia à República: um estudo dos conceitos de civilização e progresso na cidade do Rio de Janeiro entre 1868 e 1906. Tese. Programa de Pós-graduação em História Social da Cultura, Departamento de História da Pontifícia Universidade Católica do Rio de Janeiro, Rio de Janeiro, 2003.

CUNHA, Antônio G. Dicionário Etimológico. Rio de Janeiro: Nova Fronteira, 1982.

HELLER, A.; FEHÉR, F. A condição pósmoderna. Rio de Janeiro: Civilização Brasileira, 1998.

FRASER, Nancy. Reenquadrando a justiça em um mundo globalizado. Lua Nova, São Paulo, n. 77, p. 11-39, 2009.

Da distribuição ao reconhecimento? Dilemas da justiça na era "pós-socialista". Tradução de Julio Assis Simões. Cadernos de campo, São Paulo, n. 14/15, p. 231-239, 2006

HOBSBAWM, Eric J., 1917-2012. Barbárie: Manual do Usuário. In. Sobre História. São Paulo: Companhia das Letras, 2013.

HONNETH, Axel (2004). Recognition and Justice: Outline of a Plural Theory of Justice. Acta Sociologica, vol 47 n. 4, p. 351-364.

HONNETH, AXEL. Luta por reconhecimento: a gramática moral dos conflitos sociais. São Paulo: Editora 34, 2003.

MACHADO, José Pedro. Dicionário etimológico da língua portuguesa. Lisboa: Livros Horizonte, 1990.

MATTÉl, Jean-François. A barbárie interior: ensaio sobre o i-mundo moderno. Tradução: Isabel Maria Loureiro. São Paulo: Editora Unesp, 2002.

MENDONÇA, Ricardo Fabrino (2007). Reconhecimento em debate: os modelos de Honneth e Fraser em sua relação com o legado habermasiano. Revista de Sociologia e Política, Curitiba, n. 29, p.169-185, nov. 


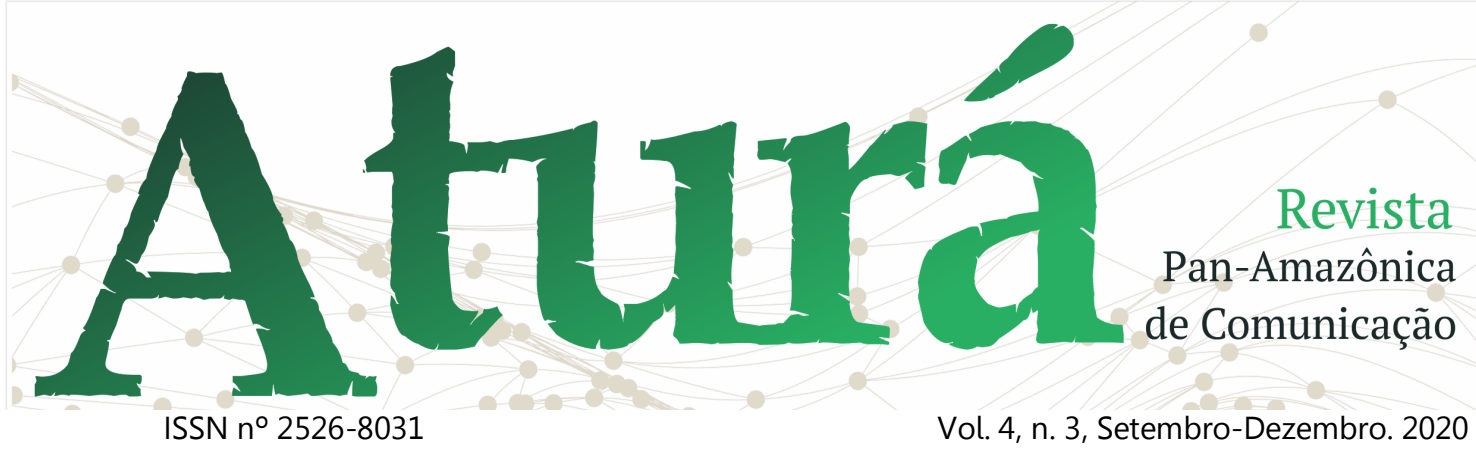

PIZZIO, Alex. A esfera do trabalho como lócus de justiça social. Revista Brasileira de Desenvolvimento Regional, Blumenau, Universidade Regional de Blumenau, 1 (1), p. 5-31, Outono de 2013.

SILVA, Antonio de Moraes. Diccionario da Lingua Portugueza. Composto pelo Padre D. Rafael Bluteau, Reformado e Acrescentado por Antonio de Moraes Silva. 4 Ed. Lisboa: Oficina de Simão Thaddeo Ferreira, 1831.

SOBOTTKA, Emil. Reconhecimento: novas abordagens em teoria crítica. São paulo: Annablume, 2015.

SOUZA, Jessé. Uma teoria crítica do reconhecimento. Lua Nova, São Paulo, n. 50, p.133-158, 2000.

STAROBINSKI, Jean. As Máscaras da Civilização.São Paulo: Cia da Letras, 2001.

SILVA, Sidney Reinaldo. A civilização contra a tradição no projeto iluminista de Condercet. Disponível em: <http://www.anped.org.br/sites/default/files/ gt17-3001-int.pdf $>$. Acessado em 23 nov 2019.

WOLFF, Francis. In: NOVAES, Adauto (org.). Civilização e barbárie. São Paulo: Companhia das Letras, 2004. 